\title{
Exploitation of cloud computing in management of construction projects in Slovakia
}

DOI 10.1515/otmcj-2016-0014

Received October 17, 2016; accepted December 24, 2016

\begin{abstract}
The issue of cloud computing is a highly topical issue. Cloud computing represents a new model for information technology (IT) services based on the exploitation of Web (it represents a cloud) and other application platforms, as well as software as a service. In general, the exploitation of cloud computing in construction project management has several advantages, as demonstrated by several research reports. Currently, research quantifying the exploitation of cloud computing in the Slovak construction industry has not yet been carried out. The article discusses the issue of exploitation of cloud computing in construction project management in Slovakia. The main objective of the research is to confirm whether factors such as size of construction enterprise, owner of construction enterprise and participant of construction project have any impact on the exploitation level of cloud computing in construction project management. It includes confirmation of differences in use between different participants of the construction project or between construction enterprises broken down by size and shareholders.
\end{abstract}

Keywords: cloud computing, exploitation, management of construction projects

\footnotetext{
*Corresponding author: Tomáš Mandičák, Technical University of Košice, Faculty of Civil engineering, Vysokoškolská 4, 04200 Košice, Slovakia, E-mail: tomas.mandicak@tuke.sk

Peter Mesároš and Mária Kozlovská, Technical University of Košice, Slovakia
}

\section{Introduction}

The exploitation of information and communications technology (ICT) is a highly topical issue in every field (Kršák et al. 2011). The same is true in the field of construction. ICT is a broad term (Čarnický and Mesároš 2009) that involves several kinds of technologies. Cloud computing is one of the forms of ICT in every field. The issue of cloud computing in construction project management is discussed in this article. Cloud computing has been the subject of several studies and a number of surveys. Potential risk factors have been investigated by Xie and Zhao (2013). Furht and Escalante (Furth et al. 2010), in their publication entitled "Handbook of Cloud Computing", discuss the basics of cloud computing for every industry. Cloud computing represents a new model for providing information technology (IT) services. It uses the Internet (cloud) as a means of providing infrastructure, application platforms and software as a service (Furht et al. 2010).

The construction sector is one of the areas which provides space for innovation and use of new, advanced or progressive technologies (Kozlovská et al. 2015; Mačková and Bašková 2014), e.g. technologies such as cloud computing. Implementation and exploitation of cloud computing has been the subject of research in the construction field or civil engineering industry. The issue of data management in building information modelling (BIM) based on cloud computing in architecture, engineering, construction and facilities management has been discussed by Jiao et al (2013). The use of BIM based on cloud computing has also been addressed by Chuang et al. (2012). Cloud computing has been the subject of investigations by other authors in construction project management; the review is contained in Table 1.

The issue of cloud computing exploitation in the construction field in Slovakia has already been discussed (Table 1). Some authors have dealt with the schedules of construction output in the cloud environment (Červeňák et al. 2013). However, from the available information, it can be said that Slovakia has not yet conducted any 
Tab. 1: Review of foreign research and publications on cloud computing in construction project management.

\begin{tabular}{lll}
\hline Authors (year) & Article or topic & Country \\
\hline Lorio and & Leveraging Cloud Computing and High & Canada \\
Snowdon & $\begin{array}{l}\text { Performance Computing Advances for } \\
\text { (2010) }\end{array}$ & \\
& $\begin{array}{l}\text { Next-Generation Architecture, Urban } \\
\text { Design and Construction Projects }\end{array}$ & \\
Fathi et al. & $\begin{array}{l}\text { Context-Aware Cloud Computing for } \\
\text { (2012) }\end{array}$ & Malaysia \\
Kumar and & Construction Collaboration & \\
Chang (2012) & Construction IT \\
Chuang et al. & Applying Cloud Computing Technology to & Taiwan \\
(2012) & BIM Visualization and Manipulation & \\
jiao et al. & A Cloud Approach to Unified Lifecycle & China \\
(2013) & Data Management in Architecture, & \\
& Engineering, Construction and Facilities & \\
& Management: Integrating BIMs and & \\
& Social networking services & \\
\hline
\end{tabular}

Source: Own processing.

research to quantify the use of cloud computing for the purposes of construction project management. Quantification of the exploitation rate is important for assessing the current situation in the field. Similarly, Kovacic et al. (2015) conducted research on the principles of technology acceptance model (TAM) for the use of BIM in construction. Based on this cited information, this article intends to quantify the exploitation level of cloud computing in construction project management in Slovakia. The state of the exploitation of cloud computing will be appraised on the basis of parameters such as construction enterprise size, majority owner of the construction enterprise and participant of construction project.

Cloud computing represents a new model for IT services based on the exploitation of Web (it represents a cloud) and other application platforms, as well as software as a service. The main requirements for exploitation of cloud computing are availability of Internet or intranet (Čarnický and Mesároš 2009). Users can access the programmes, applications and data with a computer, laptop, smartphone or personal digital assistant (PDA) through the Internet and intranet. The requirements for each kind of network vary depending on the model of cloud computing. The Internet (Web platform) represents a means of providing infrastructure (Furht et al. 2010). The content of the Internet is available for a wide group of users (Bargas-Avila et al. 2009). An intranet represents a network of linked devices (computers and so on) to which only a restricted group of organization members have access (Hoffmann 2001). Cloud computing also provides new opportunities for data management in the construction field (Jiao 2013).
Cloud computing is a technology used to access the services offered in the Internet cloud (Chuang et al. 2012). Cloud computing can be divided into three basic services that are useful for various purposes in the construction industry (Mell and Grance 2011):

- Software as a service (SaaS)

- Platform as a service (PaaS)

- Infrastructure as a service (IaaS)

The term SaaS (software as a service) refers to services provided mainly to corporate customers through applications running on the shared infrastructure of the provider (Calero et al. 2012). PaaS (platform as a service) is a service where virtual development environments such as Java, .NET and so on are made available to end users. This allows customers to develop their own applications. IaaS (infrastructure as a service) is a service to rent virtual computing, network and storage resources, using which the end user can implement and run any operating system and applications.

Cloud computing used in the construction industry has several models: private cloud, public cloud and hybrid cloud (Čarnický and Mesároš 2009).

Private cloud (Furht et al. 2010) is used in construction enterprises with their own network or data centres. This cloud model is operated exclusively for the enterprise or organization, or for the management of a particular construction project. This model mostly favours organizations that want to have more control over data, e.g. specific economic data on construction projects and so on.

Public cloud is the most widely used cloud computing model. Services are available to the general public. Individual users or construction enterprises access the services of another provider via the Internet.

Hybrid cloud model of the cloud is a combination of the private and public models. This role of cloud computing in the construction field has been specified by Kumar and Cheng (2012) and is shown in Fig. 1, which describes the relationships and information flows in a hybrid cloud model. Document management can include more kinds or fields of management, e.g. management of contracts, building permits, regulations and other documents. A large variety of relationships and flows are formed between participants and BIM technology. Points from one to five present the kind of relationship or information flow. For example, the number 1 describes the relationship between the participants of the construction project (between project manager and new project participants). Information flow 2 presents the inputs from the participant to the computer-aided design (CAD) system. The next information flows are within the CAD system 


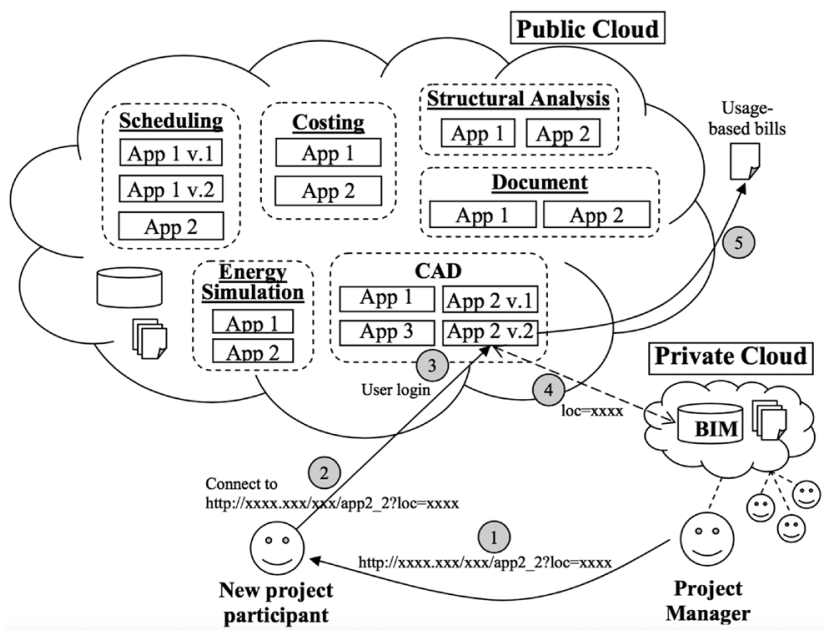

Fig. 1: Flow diagram of cloud computing in construction project management (Kumar and Cheng 2012).

(information needed for modeling, internal data change). Subsequently, this information flows to the BIM module (point 4). The final step is the production of the document and its usage (e.g. usage-based bills). This is point 5 .

Červeňák et al. (2013) have outlined the problems associated with exploitation of cloud computing in construction project management, mainly in terms of generating timetables based on hybrid cloud. Hybrid cloud systems are among the most common cloud implementation models. These systems represent a transitional model between clean, pure cloud-based and on-premise solutions. It is a combination of elements both of the previous approach. The most widespread exploitation of cloud computing is in Slovakia (InfoWare 2014). It must be said that in recent years, any survey that would assess the current state of the exploitation of cloud computing in construction project management in Slovakia has been not conducted. Considering this issue, it is important to answer the following questions: What is the average level of utilization of cloud computing in construction project management? What is the impact of individual factors such as the size of construction enterprises, their owners and participants of the building project on the exploitation of cloud computing? Is exploitation rate or level depending on these factors?

\section{Methodology of research}

\subsection{Objectives of research and methodical procedure}

The research on cloud computing exploitation should give answers to the research questions that were set up, namely, what is the average exploitation level; what are the differences in exploitation level between participants of construction projects or between size groups of construction enterprises.

The main objective of the research is to confirm whether factors such as size of construction enterprise, owner of construction enterprise and participant of construction project have an impact on the exploitation level of cloud computing in construction project management, i.e. confirmation of differences in use between different participants of the construction project or between construction enterprises broken down by size and shareholders.

The first step to achieve these objectives was to define the average level of exploitation of cloud computing. Average exploitation level of cloud computing presents the weighted average of all the participants of the research on a Likert scale. Respondents had the opportunity to assess the degree of cloud computing exploitation (from one, indicating minimal use, to five, representing maximal use) in construction project management. The average exploitation level of cloud computing was compared with the reference value of 3.5. Good use of ICT was concluded if the value of average exploitation level reached 3.5 or higher (Chii and Liu-Yang 2011). The obtained data were analysed and assessed on the basis of factors such as size of the construction enterprise, owner of construction enterprise and participant of construction project. The same was done for each group (e.g. large enterprises, medium-sized enterprises, small enterprises and so on).

The basic question for the participants of the survey was set as follows:

- What is the exploitation level of cloud computing technology for construction project management in your company? (1 presents the minimal rate, cloud computing is not used in your construction project management; and value 5 is the maximal rate, which means that cloud computing is used every day.)

On the basis of answers mentioned by the participants of the survey, further research questions were set as follows:

- What is the exploitation level of cloud computing generally?

- What are differences in exploitation of cloud computing between research groups?

- Do factors (enterprise size, enterprise owner and participants of construction projects) have impact on exploitation of cloud computing in construction project management? 


\subsection{Data collection}

All data (answers on exploitation level of cloud computing) were collected through an online questionnaire. The questionnaire was designed and distributed in electronic form (online). The questionnaire was based on the online platform Formees, which permits the questionnaire to be presented in electronic form (Rclick, 2016).

The research sample comprised participants of construction projects, represented by Slovak construction enterprises, approached by e-mail with the request to participate in the research. In total, 1,276 respondents were approached (participants of construction projects). Totally, the research included answers from 125 respondents (all sizes of enterprises), but only 55 completed the entire questionnaire to use in our research.

\subsection{Research sample}

The main characteristics of the research subjects in terms of the size of the enterprise can be seen in Fig. 2. Thus, $34.55 \%$ of micro-sized enterprises, $30.91 \%$ of small-sized enterprises and $21.82 \%$ of medium-sized enterprises, constituting $22.15 \%$ of the research sample, and $12.73 \%$ of large enterprises participated in the research. The figure shows further characteristics of the research sample (owner of construction enterprise, participant of construction project). Important view on research sample is presented in Fig. 2.

\subsection{Data processing}

The obtained data were evaluated based on several statistical methods using the software MS Excel and Statistica
(Quest Software 2016). Processing of research results was based on the descriptive and inductive statistics.

Evaluation of data was based on the use of so-called exploitation rate. Arithmetic average of the selected area was determined by the average value. The range was fixed by a Likert scale (1-5). Using the arithmetic mean of the values for the selected area under consideration, the measurement was made.

Statistical significance was tested by Kruskal-Wallis test at the significance level $\alpha=0.05$. The Kruskal-Wallis test (Kruskal-Wallis analysis of variance [ANOVA]) is a direct generalization of the Wilcoxon two-sample test case for independent samples. Kruskal-Wallisow test is similar to the non-parametric one-way ANOVA (Markechová et al. 2011).

Kruskal-Wallisow assay is based on the ranks. This is a non-parametric method for testing. Research samples were tested to find whether they were of equal distribution. It is used to compare two or more samples of the same or different sizes (Corder and Foreman 2009; Kruskal and Wallis 1952).

\section{Results and discussion}

Generally, exploitation of ICT is important in construction project management. This statement includes most of the construction enterprises in Slovakia, regardless of their size. The research results also show tangible benefits of ICT exploitation. The main advantages of using ICT include improving the quality of documents, eliminating errors in documentation, reducing the cost of the process for construction projects (communication, exchange of information and documents, as well as coordination activities)
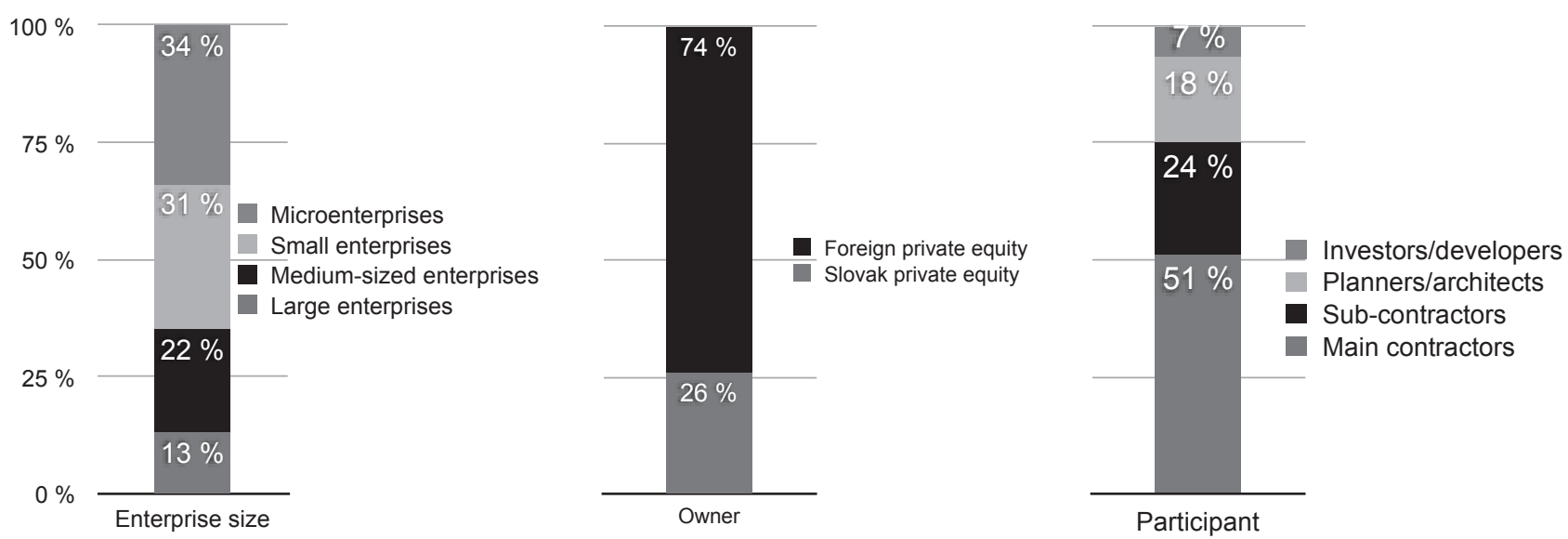

Fig. 2: Characteristics of the research sample (breakdown according to size of construction enterprise, owner of construction enterprise and participants of construction project). 


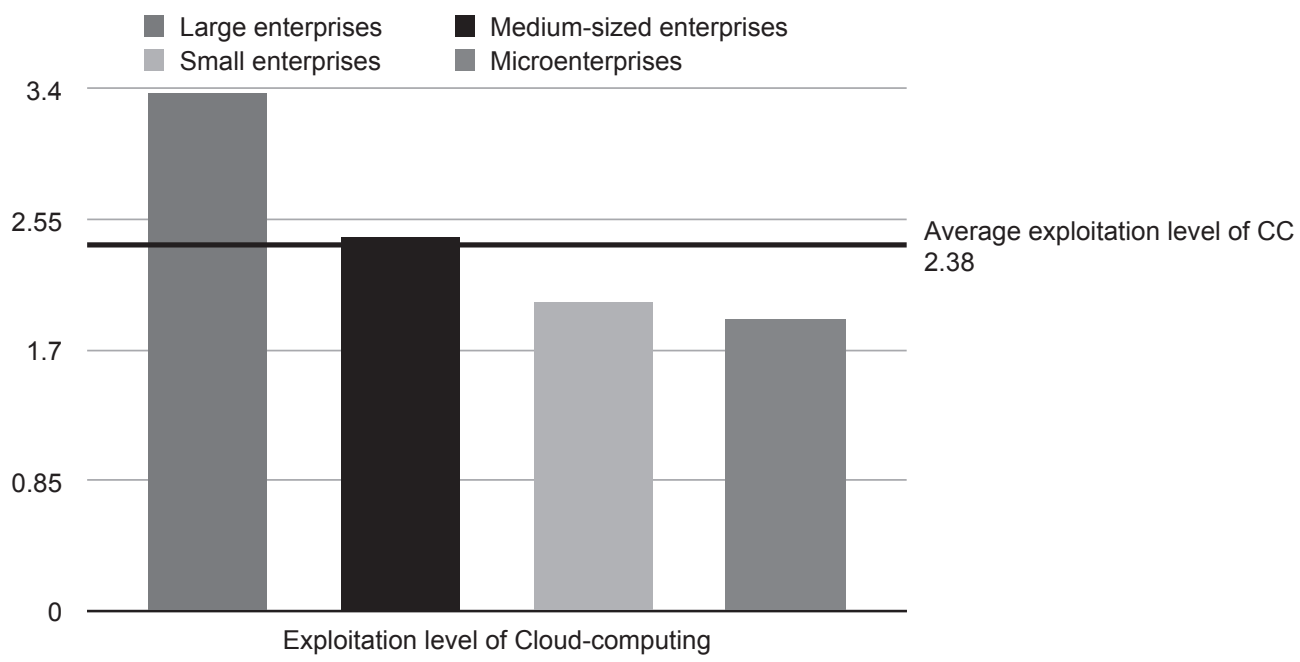

Fig. 3: Impact of construction enterprise on exploitation of cloud computing in construction project management. CC, cloud computing.

and saving in terms of the time consumed in document processing. Cloud computing unquestionably also has several advantages. These benefits result from the implementation and use of cloud computing. Important thing is to assess the current state of the exploitation of cloud computing in the management of construction projects in Slovakia. The average exploitation level of cloud computing is 2.38 in construction project management in Slovakia. This overall indicator is a very low value. Sufficient value is more than 3.5 (Chii and Liu-Yang 2011). In this case, 2.38 is less than 3.5. Based on this fact, the overall use of cloud computing in Slovak construction enterprises is weak. Table 2 and Fig. 3 describe the exploitation level of cloud computing, depending on the size of the construction enterprise. Large construction enterprises use ICT to a greater extent, as seen in previous research. It was therefore very necessary to monitor whether this is true in the case of the use of cloud computing.

Tab. 2: Impact of construction enterprise on exploitation of cloud computing in construction project management (results of Kruskal-Wallis ANOVA based on ranking*).

\begin{tabular}{|c|c|c|c|}
\hline Size of enterprises & Code & $\begin{array}{l}\text { Number of valid } \\
\text { responses }\end{array}$ & Exploitation level \\
\hline Large enterprises & 1 & 7 & 3.37 \\
\hline $\begin{array}{l}\text { Medium-sized } \\
\text { enterprises }\end{array}$ & 2 & 12 & 2.43 \\
\hline Small enterprises & 3 & 17 & 2.01 \\
\hline Microenterprises & 4 & 19 & 1.89 \\
\hline
\end{tabular}

Notes: *Kruskal-Wallis ANOVA based on ranking; variable: size of construction enterprise; $p=0.0403$.

Source: Own processing.
Large enterprises have achieved exploitation rate at the level of 3.37. In general, it is a relatively poor level of use. Breakpoint is a value of 3.5. Other enterprises are even worse in the use of cloud computing. Medium-sized enterprises have reached the exploitation rate 2.43 and small enterprises have reached exploitation rate at the level of 2.01. Based on this, it can be concluded that large enterprises use cloud computing to a greater extent. This claim was confirmed by the Kruskal-Wallis test. The Kruskal-Wallis test confirmed the statistical significance of the results of responses (Table 2). Large enterprises in many cases have more available funds. Investments in these enterprises represent higher volumes. Large enterprises are looking for space in automation processes. Several large enterprises reported efforts to innovate in ICT, generally.

Another point of view is to monitor the results depending on the enterprise structure by the majority shareholder. Research has shown that enterprises with Slovak private equity invest less in innovation in the form of various ICT tools (Mačková and Bašková 2014). The result therefore indicates that the use of cloud computing is to a lesser extent. Table 3 and Fig. 4 present the exploitation rate of cloud computing according to the majority owner.

Construction enterprises with foreign private equity more frequently use cloud-based tools for sharing and storing documents. Conversely, companies with Slovak private equity are more conservative and often expressed concern about the security of data and documents, in particular the use of cloud services. Exploitation rate of construction enterprises with Slovak private equity is only 1.83 . This value is very low. Exploitation 
Tab. 3: Results of Kruskal-Wallis ANOVA based on ranking (breakdown of enterprises by owner of construction enterprise*).

\begin{tabular}{llll}
\hline Equity holder & Code & $\begin{array}{l}\text { Number of valid } \\
\text { responses }\end{array}$ & Exploitation level \\
\hline Slovak private equity & 1 & 44 & 1.83 \\
Foreign private equity & 2 & 11 & 3.46 \\
\hline
\end{tabular}

Notes: *Kruskal-Wallis ANOVA based on ranking; variable: owner of construction enterprise; $p=0.0256$.

rate achieved by construction enterprises with foreign private equity was 3.46. Although this value is not more than 3.5 , construction enterprises with foreign private equity definitely used cloud computing to a larger extent and more significantly than construction enterprises with Slovak equity. This may be a result of pressure from abroad. Construction enterprises exploiting foreign private equity have more money, face more pressure to innovate and possess know-how in various fields, e.g. ICT. Statistical significance of differences in the use of cloud computing was confirmed by the Kruskal-Wallis test $(p=0.0231)$.

Another important point of view is a participant in the construction project. The construction project is characterized by a large number of participants who have different interests. These participants may also have many interests that may be the same or identical. For example, efforts to automate processes to reduce costs, ensure better quality of documents and so on. The research results can be seen in Fig. 5.

Investors and developers have achieved exploitation rate at the level of 3.11. The most exploitation rate was achieved by designers and architects. They achieved
Tab. 4: Results of Kruskal-Wallis ANOVA based on ranking (breakdown of enterprises by participants of construction project*).

\begin{tabular}{|c|c|c|c|}
\hline Participants & Code & $\begin{array}{l}\text { Number of valid } \\
\text { responses }\end{array}$ & Exploitation level \\
\hline Investor/developer & 1 & 4 & 3.11 \\
\hline $\begin{array}{l}\text { Designers/ } \\
\text { architects }\end{array}$ & 2 & 9 & 3.48 \\
\hline Contractors & 3 & 28 & 2.03 \\
\hline Subcontractors & 4 & 33 & 1.54 \\
\hline
\end{tabular}

Notes: *Kruskal-Wallis ANOVA based on ranking; variable: participant of construction project; $p=0.0231$.

3.48 exploitation rate. It is a relatively good level of cloud computing exploitation, in spite of the fact that it did not reach the value 3.5 and more. Other participants (contractors and subcontractors) are worse in the use of cloud computing. It includes the value 2.03 for contractors and only 1.54 for subcontractors. Statistical significance was confirmed by the Kruskal-Wallis test (Table 4). Only selected construction enterprises reached value of 3.5. The connection with value 3.5 and more has been linked in the preceding sentences. Only factors such as construction enterprise size and owner of a construction enterprise have impact on exploitation of cloud computing in construction project management. The breakdown of the project participants is not based on enterprise size; however, there was a situation where these groups amounted to exploitation level lower than the value of 3.5. For example, a group of investors consists of some large enterprises as well as small enterprises. Although the exploitation level was associated with the enterprise size and the representation of large and small enterprises

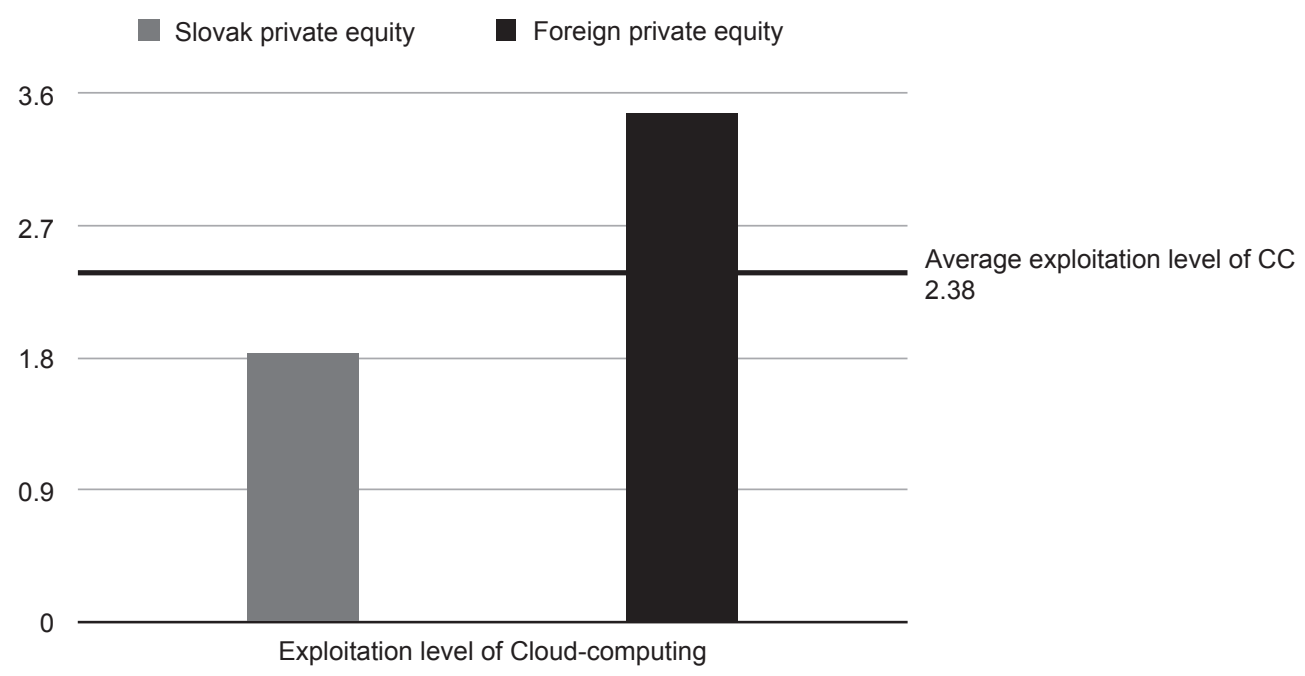

Fig. 4: Exploitation of Cloud computing in Slovak construction enterprises (breakdown by owner of construction enterprise). CC, cloud computing. 


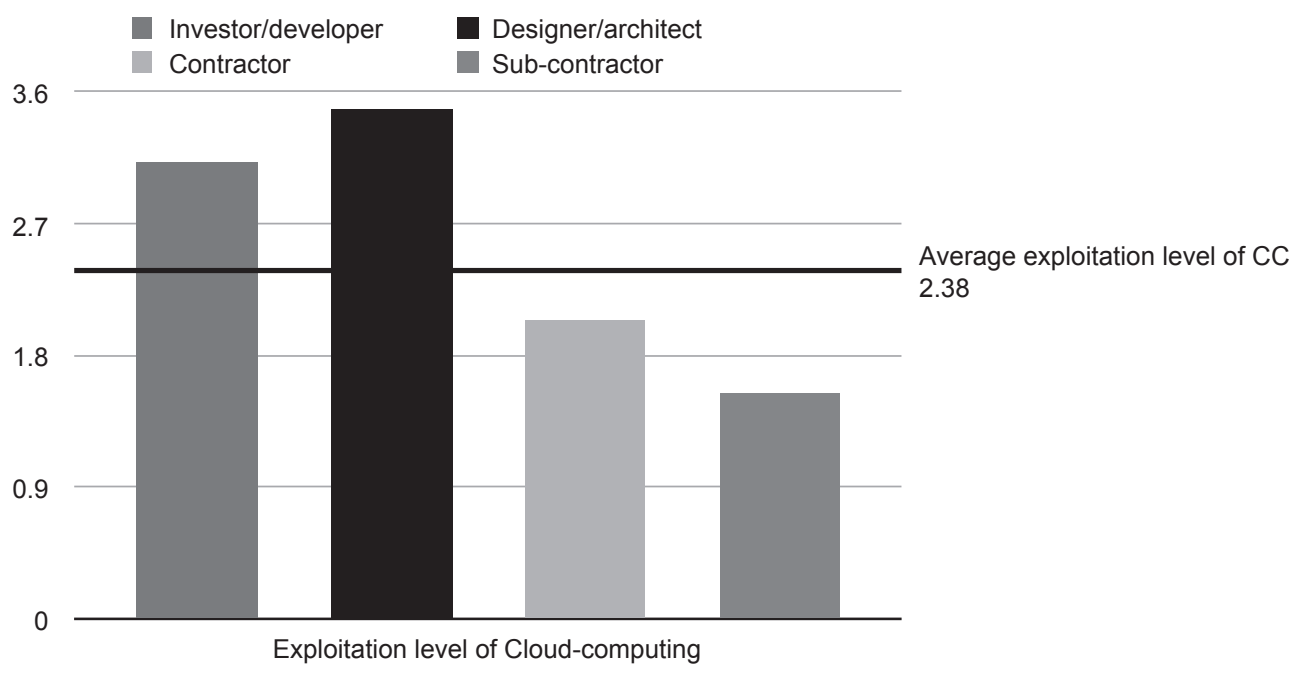

Fig. 5: Exploitation of cloud computing in Slovak construction enterprises (breakdown by participants of construction project). CC, cloud computing.

was relatively similar in all groups, any group did not have more than a given limit.

\section{Conclusion}

The issue of cloud computing is a very hot topic in every field. Several studies have been carried out on this subject, but the quantification of the use of this tool in the Slovak construction industry has not yet been mapped. This article provides insight into the current situation of the exploitation of cloud computing in terms of Slovak construction project management. In general, it can be said that use of this instrument has not extended to such an extent as other ICT tools. Research showed that exploitation of cloud computing is affected by size of construction enterprise and owner of a construction enterprise, which was confirmed by Kruskal-Wallis tests. Different results were also recorded in the exploitation of different groups of construction projects. Exploitation of cloud computing in large enterprises is greater than in small enterprises. Large enterprises achieved exploitation level of 3.37 in cloud computing. Small enterprises achieved exploitation level of 2.01. Kruskal-Wallis test confirmed the differences between results of enterprise size. The same is true in terms of the results of exploitation level of cloud computing based on breakdown of construction enterprises by owner. Exploitation level of cloud computing in construction enterprises with Slovak private equity was only 1.83. Exploitation level of cloud computing in construction enterprises with foreign private equity was 3.46. The research mapped the current situation in the exploitation of cloud computing in construction project management in Slovakia. The research results may represent a starting point for more detailed research in this area.

\section{Acknowledgement}

The paper presents a partial research result of the project VEGA -1/0677/14 entitled "Research of construction efficiency improvement through MMC technologies”.

\section{References}

Bargas-Avila, J., Lötscher, J., Orsini, S., \& Opwis, K. (2009). Intranet satisfaction questionnaire: Development and validation of a questionnaire to measure user satisfaction with the Intranet. Computer in Human Behaviour, 28, pp. 1241-1250.

Calero, J., König, B., \& Kirschnick, J. (2012). Cross-Layer Monitoring in Cloud Computing. Rashvand, Using Cross-Layer Techniques for Communication Systems. Premier reference source. IGI Global, Hershey, PA, p. 329. ISBN 978-1-4666-0961-7.

Čarnický, Š., \& Mesároš, P. (2009). Informačné systémy podnikov. Ekonóm, Bratislava, p. 233. ISBN 978-80-225-2676.

Červeňák, D., Janič, P., \& Tomková, D. (2013). Harmonogram stavebnej výroby v prostredí cloudu. Zborník vedeckých prác: Oceňovanie a riadenie stavebných projektov. Technická univerzita v Košiciach, Košice.

Chii, L., \& Liu-Yang, J. (2011). Use of information and communication technologies. Journal of Technologies and Computers, 13 , pp. 56-64.

Chuang, T., Lee, B., \& Wu, I. (2012). Applying cloud computing technology to BIM visualization and manipulation. Journal of Multidisciplinary Sciences, 4, pp. 144-149.

Corder, G. W., \& Foreman, D. I. (2009). Nonparametric Statistics for Non-Statisticians. John Wiley \& Sons, Hoboken, pp. 99-105. ISBN 9780470454619.

Fathi, M. (2012). Context-aware cloud computing for construction collaboration. Journal of Cloud Computing, 6, pp. 1-11.

Furht, B., \& Escalante, A. (2010). Handbook of Cloud Computing. Springer Science Business Media, New York, NY. ISBN 978-1-4419-6524-0. 
Hoffmann, C. (2001). Das Intranet: ein Medium der Mitarbeiter kommunikation. Vol. 9 of Medien und Märkte. UVK, Konstanz.

Infoware. (2014). Hybridné využívanie IT a cloud computing: Hybridné riešenia v IT s využitím cloud computing. IT News.

Jiao, Y., Wang, Y., Zhang, S., Li, L., Yang, B., \& Yuan, L. (2013). A cloud approach to unified lifecycle data management in architecture, engineering, construction and facilities management: Integrating BIMs and SNS. Advanced Engineering Informatics, 27, pp. 173-188.

Kovacic, I., Vasilescu, D., Filzmoser, M., Suppin, R. \& Oberwinter, L. (2015). BIM in teaching - lessons learned from exploratory study. Organization, Technology \& Management in Construction, 7(3), pp. 1358-1366, ISSN 1847-5450.

Kozlovská, M., Spišáková, M., \& Mačková, D. (2015). Company size impact on construction management documents processing and using. Advances and Trends in Engineering Sciences and Technologies, pp. 299-304. ISBN 978-1-138-02907-1. CRC Press/Balkema, Leiden.

Kršák, B., Tobisová, A., \& Sehnálková, M. (2011). Information technologies and their using during firm's financial health modelling. Transactions of the Universities of Košice, 4, pp. 35-40. ISSN 1335-2334.

Kruskal, W. H., \& Wallis, W. (1952). Use of ranks in one-criterion variance analysis. Journal of the American Statistical Association, 47(260), pp. 583-621.
Kumar, B., \& Cheng, P. (2012). Cloud computing and its implications for construction IT. Journal of ITEC, 7, pp. 1-7.

Lorio, F., \& Snowdon, L. (2010). Leveraging cloud computing and high performance computing advances for next-generation architecture, urban design and construction projects. Journal of IT, 1, pp. 118-125.

Mačková, D., \& Bašková, R. (2014). Models for initial construction time estimation. Oceñovanie a riadenie stavebných projektov. Zborník vedeckých prác. EuroScienta vzw, Brussels, pp. 101-107. ISBN 978-90-822990-1-4.

Markechová, D., Tirpáková, A., \& Stehlíková, B. (2011). Základy štatistiky pre pedagógov. UKF, Nitra. ISBN 978-80-8094-899-3.

Mell, P., \& Grance, T. (2011). The NIST Definition of Cloud Computing (Technical report). National Institute of Standards and Technology: U.S. Department of Commerce. Special publication, pp. 800-145.

Quest Software. (2016). [Online]. Available at http://www.statsoft. com/Products/STATISTICA-Features/version-12.

Rclick. (2016). Formees platform - online form builder [Online]. Available at http://www.formees.com/en.

Xie, X., \& Zhao, Y. (2013). Analysis on the risk of personal cloud computing based on the cloud industry chain. The Journal of China Universities of Posts and Telecommunications, 2, pp. 104-112. 